\title{
FRONT RANGE INFRASTRUCTURE RESOURCES PROJECT Water-Resources Activities
}

Infrastructure, such as roads, buildings, airports, and dams, is built and maintained by use of large quantities of natural resources such as aggregate (sand and gravel), energy, and water. As urban areas expand, local sources of these resources are becoming inaccessible (gravel cannot be mined from under a subdivision, for example), or the cost of recovery of the resource becomes prohibitive (oil and gas drilling in urban areas is costly), or the resources may become unfit for some use (pollution of ground water may preclude its use as a water supply). Governmental land-use decisions and environmental mandates can further preclude development of natural resources. If infrastructure resources are to remain economically available, current resource information must be available for use in well-reasoned decisions about future land use. Ground water is an infrastructure resource that is present in shallow aquifers and deeper bedrock aquifers that underlie much of the 2,450-squaremile demonstration area of the Colorado Front Range Infrastructure Resources Project. In 1996, mapping of the area's ground-water resources was undertaken as a U.S. Geological Survey project in cooperation with the Colorado Department of Natural Resources, Division of Water Resources, and the Colorado Water Conservation Board.

\section{BEDROCK AQUIFERS}
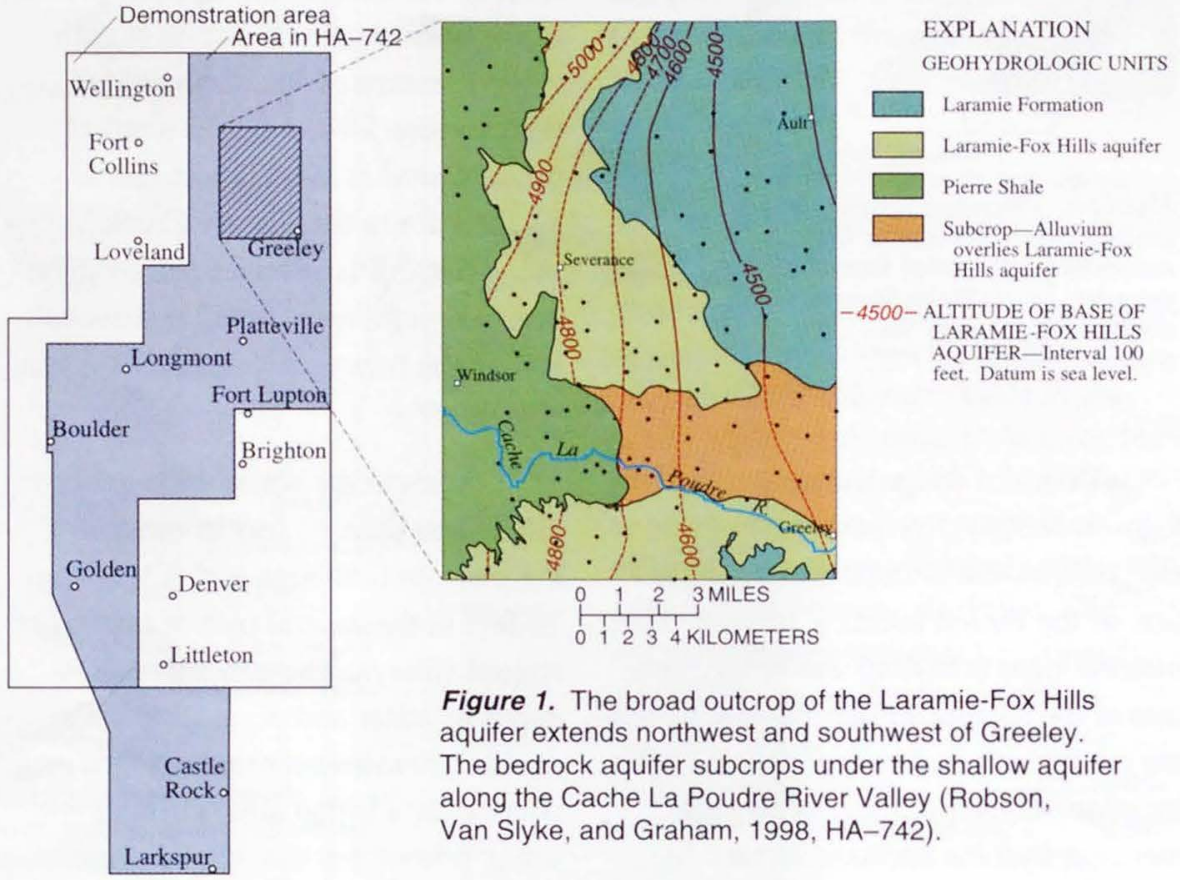

Figure 1. The broad outcrop of the Laramie-Fox Hills aquifer extends northwest and southwest of Greeley. The bedrock aquifer subcrops under the shallow aquifer along the Cache La Poudre River Valley (Robson, Van Slyke, and Graham, 1998, HA-742).

Ground water in the demonstration area is present in shallow aquifers primarily located along larger stream valleys and in deeper bedrock aquifers that extend eastward from the Front Range through thousands of square miles. Water in the shallow aquifers commonly is pumped for irrigation of crops because of low pumping costs, large well yields, and water quality that is well suited for irrigation. Water in the bedrock aquifers commonly is pumped for domestic, municipal, and commercial uses because higher pumping costs and lower well yields can be tolerated, and water quality is well suited for drinking. Thus, land-use decisions that can affect access to the aquifers or recharge to the aquifers can affect irrigation supplies and/or human water supplies.

Mapping of the outcrop and subcrop of the bedrock aquifers along the western margin of the Denver Basin was undertaken to better define the western extent of the bedrock aquifers, their outcrop recharge areas, and potential areas of subcrop water flow between shallow and bedrock aquifers (Robson, Van Slyke, and Graham, 1998).

The bedrock aquifers are composed of beds of permeable sandstone that dip eastward into the subsurface. 
In the area north of Boulder, the dip is gradual and the aquifers rise to the surface in a 2- to 7-mile-wide band of outcrop that extends to the northwest and southwest of Greeley (fig. 1). This large outcrop band is an important recharge area for the bedrock aquifers, for here rain and snowmelt can percolate to the aquifer over a large area and recharge the ground-water supply.

In the area south of Boulder, the bedrock aquifers have been more severely deformed by movement on mountainfront faults, and the exposed beds of permeable sandstone dip almost vertically into the subsurface. In this area, the outcrop band is narrow, ranging from a few hundred to a few thousand feet in width. This outcrop is a minor recharge area because of its small extent.

Where stream valleys cross the outcrop band of the bedrock aquifers, permeable sand and gravel of the shallow aquifer in the stream valley may be in direct contact with permeable sandstone of the bedrock aquifers. In these areas, called subcrop areas, ground water generally flows from the bedrock aquifer to the shallow aquifer. However, pumping may reduce the water level in the bedrock enough to cause water to flow from the shallow aquifer to the bedrock in some areas.

\section{SHALLOW AQUIFERS}

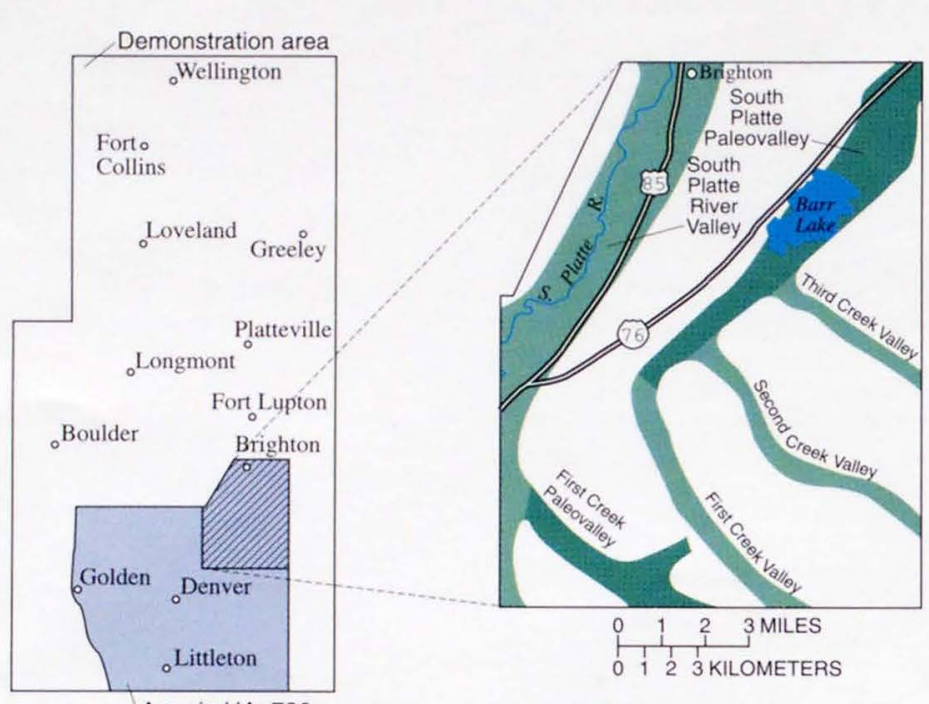

Figure 2. The present valley of the South Platte River is near Brighton. An ancient paleovalley formed by the ancestral South Platte River extends northeastward under Barr Lake (Robson, 1996, HA-736).

A map of the paleotopography in

Comprehensive mapping of the thickness, extent, paleotopography, water-table altitude, saturated thickness, and depth to water in the shallow aquifers in the 680-square-mile Denver metropolitan area has been completed (Robson, 1996). This work indicated that the alluvial sediments of the principal aquifers generally become thinner and coarser grained closer to the front range of the Rocky Mountains. Sediment thickness ranges from less than 20 feet near the mountains to 40 to 60 feet in the downstream reaches of the South Platte River near Brighton. Robson (1996) (fig. 2 is a part of this location of several paleovalleys that were cut into the bedrock surface by ancient streams which no longer flow through the areas of the paleovalleys. The largest of these paleovalleys is 1 likely was formed by the ancestral South Platte River before it changed course and cut its present deeper valley near Brighton. Alluvium in the paleovalley is as much as 60 to 90 feet thick. Ground water still flows down the trend of the paleovalley, although there is no natural stream in the present valley.

Saturated thickness of the shallow aquifers is the distance from the water table to the base of the aquifer. In most of the upland areas between stream valleys, saturated thickness is less than 20 feet. However, the areas of greatest saturated thickness (60 to 80 feet) are in the Cherry Creek Valley, in the South Platte River paleovalley, and in several other smaller paleovalleys in the metropolitan area (Robson, 1996).

Depth to the water table genermap) shows the altitude and configuration of the buried bedrock surface. The metropolitan area map shows the location of the current stream valleys, which are cut into the bedrock surface, and the to 2 miles wide and extends northeastward under Barr Lake. This paleovalley ally is less than 40 feet in most of the metropolitan area and is less than 10 feet in the central part of the larger stream valleys. The general shallow depth to water and permeable soils enable ground-water recharge to occur over a broad area. Ground water flows from the upland areas toward the nearby stream valleys where the water flows down the valley and toward the stream. Ground water discharges from the aquifer by flowing into streams, by withdrawal from wells, or by evaporation and transpiration from vegetation. 

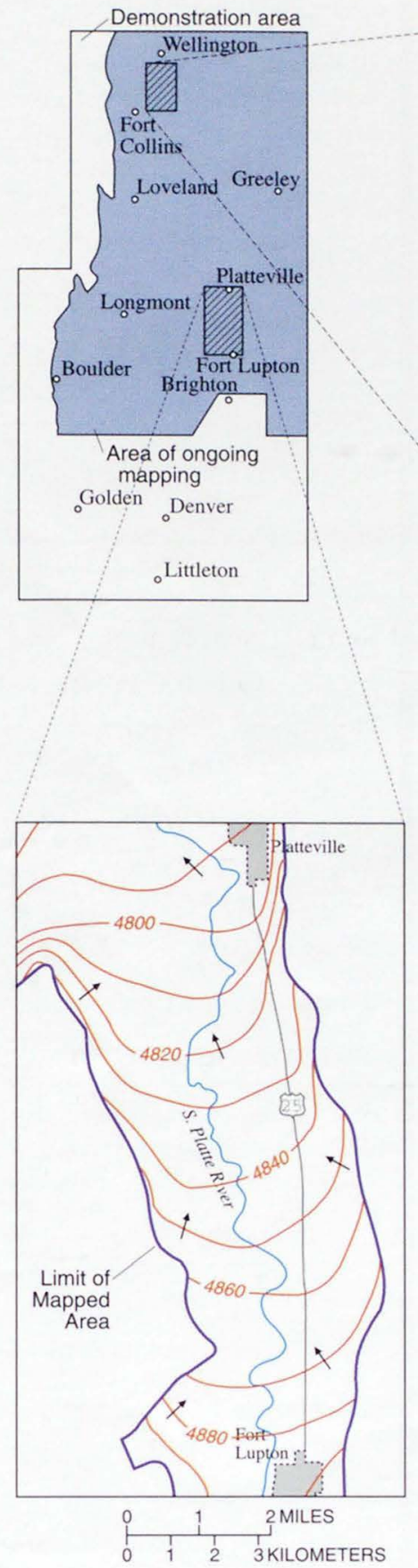

EXPLANATION

千4880-WATER-TABLE ALTTTUDEInterval is 10 feet. Datum is direction of ground-water
dirat movement

Figure 4. The water table between Fort Lupton and Platteville slopes down the valley and toward the South Platte River (Hurr, Schneider. and others, 1972)

Work is in progress to expand the comprehensive mapping of the shallow aquifers into the area north of the Denver metropolitan area. Planned products include 1:50,000-scale maps

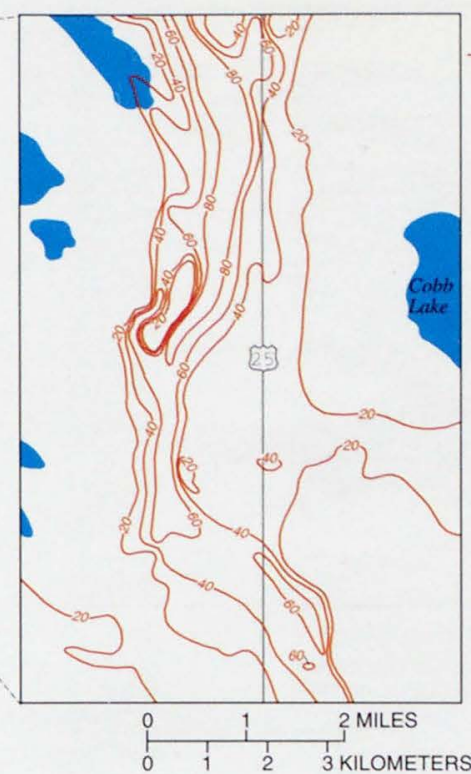

Figure 3. Thick unconsolidated sediments extend along a paleovalley cut in the bedrock surface (Stollar, 1969).

of (1) the thickness of the unconsolidated sediments, (2) the paleotopography of the buried bedrock surface, (3) the altitude of the water table and direction of ground-water movement, (4) the saturated thickness of the shallow aquifers, and (5) the depth to ground water.

As of July 1998, data for about 11,000 wells and test holes were compiled, checked, and interpreted to produce a data base defining the thickness of the unconsolidated sediments and the altitude of the water table in the 1,780-square-mile area. Data have been plotted and contoured at 1:24,000 scale to produce preliminary maps showing thickness of unconsolidated sediments and altitude of the water table. The maps have been scanned to produce ArcINFO coverages that are being checked and attributed prior to use in preparation of the paleotopography, saturated thickness, and depth-to-water maps.

Results of mapping the thickness of the unconsolidated sediments indicate that the alluvium in the principal stream valleys continues to thicken in the downstream direction between Brighton and Greeley. Thick sediments also are present along paleovalleys in various parts of the area of ongoing mapping. For example, in the area northeast of Fort Collins, thick sediments define a paleovalley first mapped by Stollar (1969) in an area of rolling topography having no natural stream channels (fig. 3). Unconsolidated sediments are 0 to 40 feet thick beyond the northward-trending paleovalley; sediments are as much as 80 to 100 feet thick within the paleovalley.

Preliminary results of mapping the altitude of the water table are in general agreement with previous mapping available for parts of the area. For example, in the South Platte River Valley near Platteville (fig. 4), Hurr, Schneider, and others (1972) indicated that the altitude of the water table was higher near the margins of the valley and lower near the South Platte River. Hurr and others (1975) indicated that ground-water flow is strongly affected by groundwater recharge, which occurs over the area of the aquifer from infiltration of irrigation water, rain, and snowmelt. Ground water flows from heavily irrigated areas near the margins of the valley toward the South Platte River, which serves as a drain that controls the altitude of the water table near the river. The direction of ground-water movement is thus down the valley and toward the river, as indicated by the arrows in figure 4 .

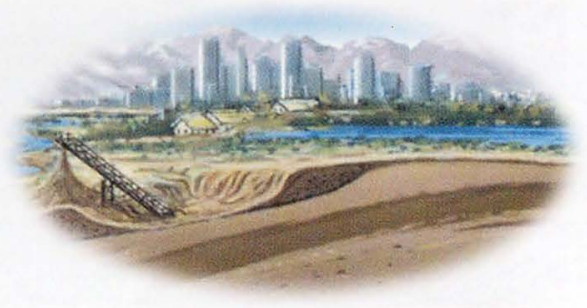




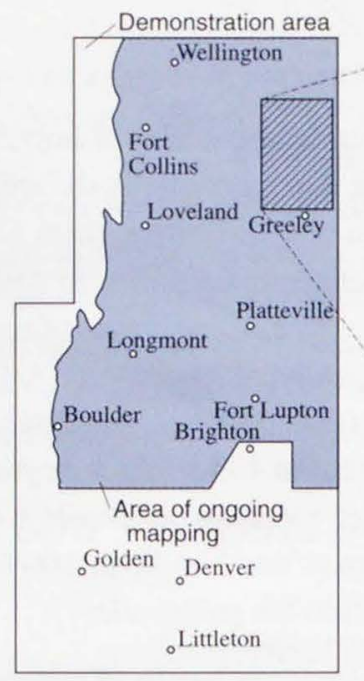

A comprehensive review of existing water-quality analyses is being conducted to define the chemical quality of the shallow ground water in the area of ongoing mapping. The work expands on that of previous studies (Dennehy and others, 1995; Shelton and Rogers, 1987), which have indicated that land use, depth to water table, and rate and direction of ground-water movement all can affect shallow ground-water quality. Potential constituents and sources of contamination to the shallow aquifer include heavy metals from urban and industrial areas, and nitrates (fig. 5), ammonia, phosphorus, manganese, and pesticides from urban and agricultural sources. A water-quality data base is planned.

\section{PRODUCTS}

Products of the water activities in the Front Range Infrastructure Resources Project will consist of published reports, geospatial data available through the U.S. Geological Survey web sites, and data layers for use in a project decision-support system. Two reports are in print (Robson, 1996; Robson and others, 1998), and others are planned. Geospatial data from the two published reports are available through the U.S. Geological Survey project web site at http://webserver.cr.usgs.gov/frirp/. Additional geospatial data will be released as reports and meta data are completed. Data layers for the decision-support system will be similar to those on the web site. The decisionsupport system will enable users to access project results for all or part of the demonstration area, to combine or manipulate various layers of information, and to display the results in a form they find useful.

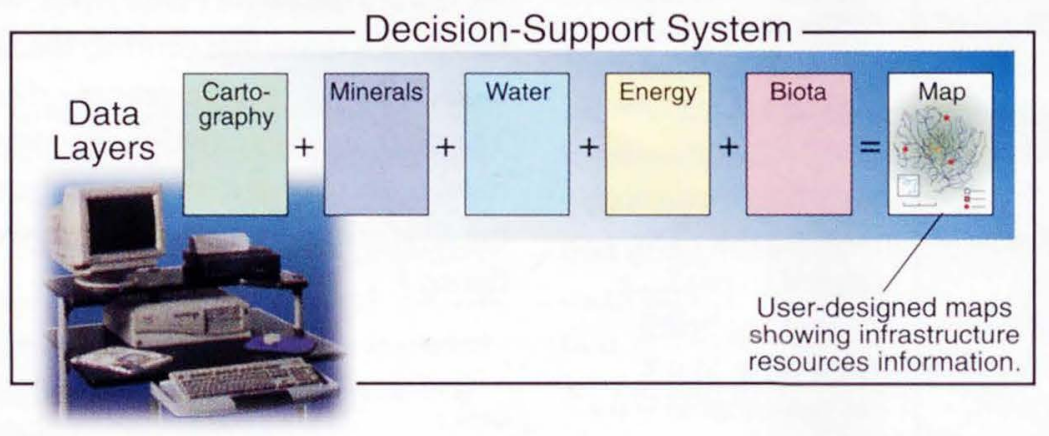

Information on technical reports and hydrologic data may be obtained from:

U.S. Geological Survey

Water Resources Division

Box 25046, Mail Stop 415

Denver, CO 80225

email: wfhorak@usgs.gov

\section{REFERENCES}

Dennehy, K.F., Litke, D.W., McMahon, P.B., Heiny, J.S., and Tate, C.M., 1995, Waterquality assessment of the South Platte River Basin, Colorado, Nebraska, and Wyoming-Analysis of available nutrient, suspended-sediment, and pesticide data, water years 1980-92: U.S. Geological Survey Water-Resources Investigations Report 94 4095, 145 p.

Hurr, R.T., Schneider, P.A., Jr., and Minges, D.R., 1975, Hydrology of the South Platte River Valley, northeastern Colorado: Colorado Water Conservation Board, Water Resources Circular 28, 24 p.

Hurr, R.T., Schneider, P.A., Jr., and others, 1972, Hydrogeologic characteristics of the valley-fill aquifer in the Brighton reach of the South Platte River Valley, Colorado: U.S. Geological Survey Open-File Report, 2 p., 6 plates, scale 1:62,500.

Robson, S.G., 1996, Geohydrology of the shallow aquifers in the Denver metropolitan area, Colorado: U.S. Geological Survey Hydrologic Investigations Atlas HA-736, 5 sheets, scale 1:50,000.

Robson, S.G., Van Slyke, George, and Graham, Glenn, 1998, Structure, outcrop, and subcrop of the bedrock aquifers along the western margin of the Denver Basin, Colorado: U.S. Geological Survey Hydrologic Investigations Atlas HA-742, 5 sheets, scale 1:50,000.

Shelton, D.C., and Rogers, W.P., 1987. Environmental and engineering geology of the Windsor study area, Larimer and Weld Counties, Colorado: Colorado Geological Survey, Environmental Geology 6 , 11 sheets.

Stollar, R.L., 1969, Applications of geophysics in hydrogeology - Boxelder Creek Valley, Colorado: Fort Collins, Colorado State University, Master's thesis, $140 \mathrm{p}$.

-S.G. Robson and J.S. Heiny 